\title{
SENSITIVITY STUDY FOR LONG TERM RELIABILITY
}

\author{
Allan L. White, NASA Langley, Hampton, VA
}

\begin{abstract}
This paper illustrates using Markov models to establish system and maintenance requirements for small electronic controllers where the goal is a high probability of continuous service for a long period of time. The system and maintenance items considered are quality of components, various degrees of simple redundancy, redundancy with reconfiguration, diagnostic levels, periodic maintenance, and preventive maintenance. Markov models permit a quantitative investigation with comparison and contrast. An element of special interest is the use of conditional probability to study the combination of imperfect diagnostics and periodic maintenance.
\end{abstract}

\section{Introduction}

The objective is to determine the system and maintenance requirements for a small electronic controller. The scenario is that the controller, except for some small downtime for maintenance, is to operate continuously for ten years. We wish the probability of failure to be less than 0.01 during this operating period. Periodic maintenance is assumed available.

The original motivation for this study was process-control of equipment for the ground control of aircraft. The study, however, applies to most transportation and manufacturing systems. It does not apply to long-duration space missions where periodic maintenance is not available.

When the requirement of reliable and continuous operation cannot be met by a single component, the architecture can use several working components configured in such a manner that the good components, up to a point, can handle the operation despite, and in the presence of, the failed components. In some systems of this type, too many failed components in the system can overwhelm or place too heavy a burden on the good components.
One response to the accumulation of failed components is to have the system itself remove them-reconfiguration. A reconfigurable system, however, demands a trade-off. It is more efficient in terms of component use, but it is more complex and more vulnerable in terms of system design. For instance, we do not want the reconfiguration algorithm to remove good components.

A requirement of a long period of operation can include maintenance to keep the original system a moderate size. There is on-demand and periodic maintenance. This study considers periodic maintenance. The assumption is that there are many systems at a facility or group of facilities, and a periodic tour of maintenance personnel is more efficient and easier to plan than emergency calls at random failure times. Part of system design is a high probability of surviving between maintenance checks.

For equipment with an exponential (memoryless) failure distribution, such as electronic components, there is no gain in replacing the equipment until it has failed. Hence, the periodic maintenance sweep only replaces components detected as faulty. Obviously, failure detection, the diagnostic level, is important.

Even though the individual components of a system do not age, the system can be regarded as ageing if failed components accumulate because of imperfect diagnostics. A possible strategy in the presence of imperfect diagnostics is preventative maintenance: on a regular basis, the entire system is replaced with a new system. This effectively breaks the long operating period into a sequence of short operating periods.

A basic element is component quality, and a general result in the field is that it is hard to drive system reliability beyond the mean-time-to-failure of the components. The final results will reflect this as two different component qualities are examined: one with mean-time-to-failure less than the operating period and one with mean-time-to-failure greater than the operating period. 
The analysis considers two component failure rates $1 \mathrm{e}-4$ per hour and $1 \mathrm{e}-5$ per hour. It considers four architectures: a threeplex, a double-dual, a reconfigurable fourplex, and a nonreconfigurable fiveplex. It considers diagnostic levels of 0.9, 0.99, 0.999 , and 1.00. It looks at daily, weekly, monthly, and yearly periodic maintenance that replaces components detected as faulty. It considers preventive maintenance with intervals 1 year, 2 years, and 5 years.

A problem is presentation of data. The tables of results can either be included in the sections which describe each system which means flipping pages to compare systems, or the tables can be collected in one section which permits easy comparison of the systems but separates the results from the description of each system. This paper chooses to group the tables together on the basis that system description (the difference between a fourplex and a fiveplex, for example) is easy to remember.

Three of the systems below use majorityvoting to detect faulty components: the three-plex, the reconfigurable fourplex, and the nonreconfigurable fiveplex. The double-dual uses comparison where a dual unit removes itself from the system when its two units disagree.

In this study, there is no explicit modeling of built-in-tests or external diagnostic equipment.

\section{Modeling Maintenance}

The behavior of a Markov model is described by a set of simultaneous differential equations.

Suppose the coefficient matrix for a set of differential equations is $\mathrm{A}$, and if the initial conditions (the initial probabilities of being in the $n$ states of the model) at time $\mathrm{T}$ are

$$
\mathbf{p}(\mathrm{T})=\left[\begin{array}{c}
\mathrm{p}_{1}(\mathrm{~T}) \\
\mathrm{p}_{2}(\mathrm{~T}) \\
\vdots \\
\mathrm{p}_{\mathrm{n}}(\mathrm{T})
\end{array}\right]
$$

then the solution to

$$
\mathbf{p}^{\prime}=\mathbf{A} \mathbf{p}
$$

at time $\mathrm{T}+\tau$ is

$$
\mathbf{p}(\mathrm{T}+\tau)=\mathrm{e}^{\mathbf{A} \tau} \mathbf{p}(\mathrm{T})
$$

which gives the probabilities of being in the $n$ states at time $\mathrm{T}+\tau$.

Modeling regular maintenance is handled by considering the conditional probability of being in all the states. Suppose the probability of being in state $j$ at time $T$ is $p_{j}(T)$. Let $e_{j}$ be the column vector with 1 in row $\mathrm{j}$ and zero elsewhere. The probability of being in any state at time $\mathrm{T}+\tau$ given we are in state $\mathrm{j}$ at time $\mathrm{T}$ is

$$
\mathbf{p}(\mathrm{T}+\tau)=\mathrm{e}^{\mathbf{A} \tau} \mathbf{e}_{\mathrm{j}}
$$

The probability of being in any state can be expressed by considering the sum over a disjoint union of sets.

$$
\begin{aligned}
\mathbf{p}(\mathrm{T}+\tau)= & \sum_{1}^{\mathrm{n}} \mathrm{P}\{\mathrm{j}\} \mathrm{P}\{\text { in } \mathbf{p}(\mathrm{T}+\tau) \mid \text { state } \mathrm{j}\} \\
& =\mathrm{p}_{1}(\mathrm{~T}) \mathrm{e}^{\mathbf{A} \tau} \mathbf{e}_{1} \\
& +\mathrm{p}_{2}(\mathrm{~T}) \mathrm{e}^{\mathbf{A} \tau} \mathbf{e}_{2} \\
& +\cdots \\
& +\mathrm{p}_{\mathrm{n}}(\mathrm{T}) \mathrm{e}^{\mathbf{A} \tau} \mathbf{e}_{\mathrm{n}} \\
& =\mathrm{e}^{\mathbf{A} \tau\left[\begin{array}{c}
\mathrm{p}_{1}(\mathrm{~T}) \\
\mathrm{p}_{2}(\mathrm{~T}) \\
\vdots \\
\mathrm{p}_{\mathrm{n}}(\mathrm{T})
\end{array}\right]}
\end{aligned}
$$

For instance, if maintenance is daily, $\tau=24$ hours. Solve the model for the first day given all 
components are good. Adjust the initial conditions for the second day by replacing all the detected failed components. For ten years, do this 3,650 times.

Preventive maintenance replaces the old system with a new system where all components are good. Suppose there are k preventive maintenance intervals of equal length for the overall operating period. Suppose Q is the probability the system fails during a preventive maintenance interval. The probability of system failure $\mathrm{P}$ for the overall operating period is

$$
\mathrm{P}=1-(1-\mathrm{Q})^{\mathrm{k}}
$$

\section{Figures and Equations for the Models}

Throughout this section, $\lambda$ is the component failure rate, $\mathrm{D}$ is the diagnostic level (the probability a fault is detected), and $\delta$ the recovery rate for the reconfigurable fourplex.

The model for a non-reconfigurable threeplex is given in figure 1. The system begins in state 1 with all components good. There is a transition at rate $3 \lambda$ to a state representing one component failed - to state 3 if the component is detected as faulty and to state 2 otherwise. The occurrence of a second fault at rate $2 \lambda$ can overwhelm or confuse the majority voter, and the system transitions to the failed state F.

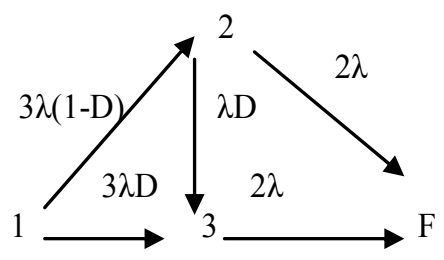

Figure 1. Markov Model Of A Threeplex

The differential equations for the model in figure 1 are

$$
\begin{aligned}
& \mathrm{p}_{1}^{\prime}=-3 \lambda \mathrm{p}_{1} \\
& \mathrm{p}_{2}^{\prime}=3 \lambda(1-\mathrm{D}) \mathrm{p}_{1}-(2 \lambda+\lambda D) \mathrm{p}_{2} \\
& \mathrm{p}_{3}^{\prime}=3 \lambda D \mathrm{p}_{1}+\lambda D \mathrm{p}_{2}-2 \lambda \mathrm{p}_{3} \\
& \mathrm{~F}^{\prime}=2 \lambda \mathrm{p}_{2}+2 \lambda \mathrm{p}_{3}
\end{aligned}
$$

The initial conditions at time 0 are

$$
\begin{aligned}
& \mathrm{p}_{1}=1 \\
& \mathrm{p}_{2}=\mathrm{p}_{3}=\mathrm{F}=0
\end{aligned}
$$

At regular maintenance, all components identified as faulty are replaced by good components. The initial conditions for the beginning of the next operating period are

$$
\begin{aligned}
& \mathrm{p}_{1}=\mathrm{p}_{1}+\mathrm{p}_{3} \\
& \mathrm{p}_{2}=\mathrm{p}_{2} \\
& \mathrm{p}_{3}=0 \\
& \mathrm{~F}=\mathrm{F}
\end{aligned}
$$

For a double-dual, a decision needs to be made on how to model two undetected faults in the same dual.

The pessimistic view is that if the faults manifest themselves simultaneously, then they will produce the same incorrect result in which case the dual believes itself correct. The system, however, has two duals that disagree which is a failure.

The pessimistic model is given in figure 2

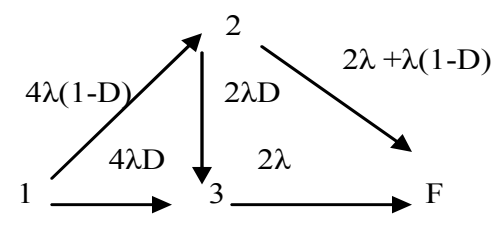

Figure 2. Pessimistic Model Of A DoubleDual 
In figure 2 , the transition from state 1 to state 2 represents the occurrence of a detectable fault while the transition to state 3 represents the occurrence of an undetectable fault. In states 2 and 3, the system has a single good dual, and a failure in this dual is system failure. The transition from state 3 to state 2 represents the occurrence of a detectable fault in the dual that has an undetectable fault. In state 2, the failed dual can be replaced during maintenance.

The equations for the pessimistic model of the double dual are:

$$
\begin{aligned}
\mathrm{p}_{1}^{\prime}= & -4 \lambda \mathrm{p}_{1} \\
\mathrm{p}_{2}^{\prime}= & 4 \lambda(1-D) \mathrm{p}_{1} \\
& \quad-(2 \lambda D+2 \lambda+\lambda(1-D)) \mathrm{p}_{2} \\
\mathrm{p}_{3}^{\prime}= & 4 \lambda \mathrm{D} \mathrm{p}_{1}+2 \lambda \mathrm{D} \mathrm{p}_{2}-2 \lambda \mathrm{p}_{3} \\
\mathrm{~F}^{\prime}= & (2 \lambda+\lambda(1-D)) \mathrm{p}_{2}+2 \lambda \mathrm{p}_{3}
\end{aligned}
$$

The initial conditions at time 0 are

$$
\begin{aligned}
& \mathrm{p}_{1}=1 \\
& \mathrm{p}_{2}=\mathrm{p}_{3}=\mathrm{F}=0
\end{aligned}
$$

At regular maintenance, all components identified as faulty are replaced by good components. The initial conditions for the beginning of the next operating period are

$$
\begin{aligned}
& \mathrm{p}_{1}=\mathrm{p}_{1}+\mathrm{p}_{3} \\
& \mathrm{p}_{2}=\mathrm{p}_{2} \\
& \mathrm{p}_{3}=0 \\
& \mathrm{~F}=\mathrm{F}
\end{aligned}
$$

The optimistic point of view is that if the faults manifest themselves simultaneously, then they will produce different incorrect results and the faulty dual can be identified as faulty. The optimistic model is given in figure 3 .

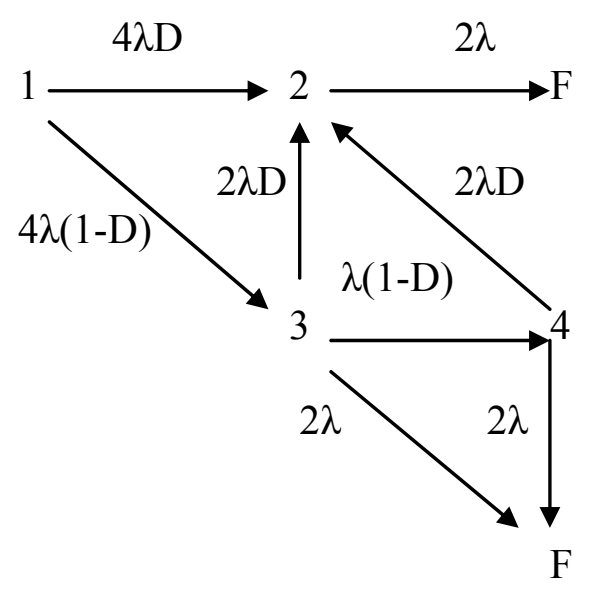

Figure 3. Optimistic Model Of A Double-Dual

In figure 3 , the system moves from state 1 to state 2 or 3 according as the fault is detectable or undetectable. In both 2 and 3, the system fails if the other dual collects a fault. The system moves from state 3 to state 2 if the dual with an undetectable fault collects a detectable fault. The system moves from state 3 to state 4 if the non-faulty component in the faulty dual collects an undetectable fault. In state 4 , the system moves to state 2 if a component in the faulty dual collects a detectable fault, and it moves to the failed state if a component in the nonfaulty dual becomes faulty.

The equations for the optimistic model of the double dual are:

$$
\begin{aligned}
& \mathrm{p}_{1}^{\prime}=-4 \lambda \mathrm{p}_{1} \\
& \mathrm{p}_{2}^{\prime}=4 \lambda \mathrm{D} \mathrm{p}_{1}-2 \lambda \mathrm{p}_{2}+2 \lambda \mathrm{D} \mathrm{p}_{3}+2 \lambda \mathrm{D} \mathrm{p}_{4} \\
& \mathrm{p}_{3}^{\prime}=4 \lambda(1-D) \mathrm{p}_{1}-(2 \lambda D+\lambda(1-\mathrm{D})+2 \lambda) \mathrm{p}_{3} \\
& \mathrm{p}_{4}^{\prime}=\lambda(1-D) \mathrm{p}_{3}-(2 \lambda D+2 \lambda) \mathrm{p}_{4} \\
& \mathrm{~F}^{\prime}=2 \lambda \mathrm{p}_{2}+2 \lambda \mathrm{p}_{3}+2 \lambda \mathrm{p}_{4}
\end{aligned}
$$

The initial conditions at time 0 are 1 for the initial state and zero for the rest.

At regular maintenance, all components identified as faulty are replaced by good components. The initial conditions for the beginning of the next operating period are 


$$
\begin{aligned}
& \mathrm{p}_{1}=\mathrm{p}_{1}+\mathrm{p}_{2} \\
& \mathrm{p}_{2}=0 \\
& \mathrm{p}_{3}=\mathrm{p}_{3} \\
& \mathrm{p}_{4}=\mathrm{p}_{4} \\
& \mathrm{~F}=\mathrm{F}
\end{aligned}
$$

For the double-dual, the question is what percentage of faults requires the pessimistic model as opposed to the optimistic model. The answer is based on experiments which are expensive, and these experiments will be conducted only if the reliability results from the two models differ significantly.

The figure for a reconfigurable fourplex is given in figure 4.

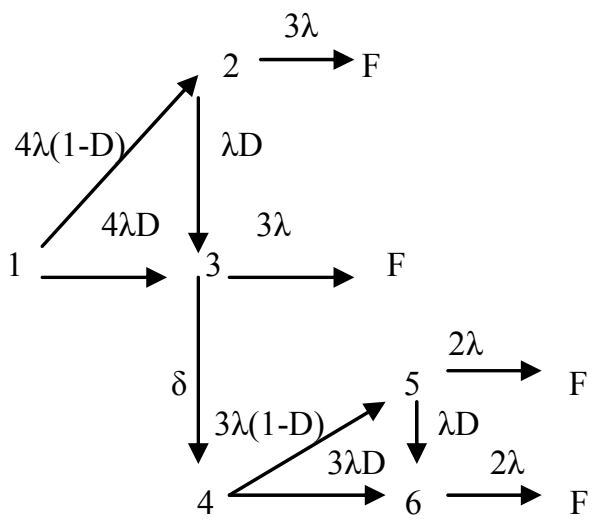

Figure 4. Model Of A Reconfigurable Fourplex

$$
\begin{aligned}
& \mathrm{p}_{1}^{\prime}=-4 \lambda \mathrm{p}_{1} \\
& \mathrm{p}_{2}^{\prime}=4 \lambda(1-\mathrm{D}) \mathrm{p}_{1}-(3 \lambda+\lambda D) \mathrm{p}_{2} \\
& \mathrm{p}_{3}^{\prime}=4 \lambda D \mathrm{p}_{1}+\lambda D \mathrm{p}_{2}-(3 \lambda+\delta) \mathrm{p}_{3} \\
& \mathrm{p}_{4}^{\prime}=\delta \mathrm{p}_{3}-3 \lambda \mathrm{p}_{4} \\
& \mathrm{p}_{5}^{\prime}=3 \lambda(1-\mathrm{D}) \mathrm{p}_{1}-2 \lambda \mathrm{p}_{5} \\
& \mathrm{p}_{6}^{\prime}=3 \lambda D \mathrm{p}_{4}+\lambda D \mathrm{p}_{5}-(2 \lambda+\lambda \mathrm{D}) \mathrm{p}_{6} \\
& \mathrm{~F}^{\prime}=3 \lambda \mathrm{p}_{2}+3 \lambda \mathrm{p}_{3}+2 \lambda \mathrm{p}_{5}+2 \lambda \mathrm{p}_{6}
\end{aligned}
$$

The initial conditions at time 0 are

$$
\begin{aligned}
& \mathrm{p}_{1}=1 \\
& \mathrm{p}_{2}=\mathrm{p}_{3}=\mathrm{p}_{4}=\mathrm{p}_{5}=\mathrm{p}_{6}=0
\end{aligned}
$$

$$
\mathrm{F}=0
$$

When regular maintenance is performed all components identified as faulty are replaced by good components. The initial conditions for the next operating period are

$$
\begin{aligned}
& \mathrm{p}_{1}=\mathrm{p}_{1}+\mathrm{p}_{3}+\mathrm{p}_{4}+\mathrm{p}_{6} \\
& \mathrm{p}_{2}=\mathrm{p}_{2}+\mathrm{p}_{5} \\
& \mathrm{p}_{3}=\mathrm{p}_{4}=\mathrm{p}_{5}=\mathrm{p}_{6}=0 \\
& \mathrm{~F}=\mathrm{F}
\end{aligned}
$$

The differential equations are 
The model for a fiveplex is given in figure 5 .

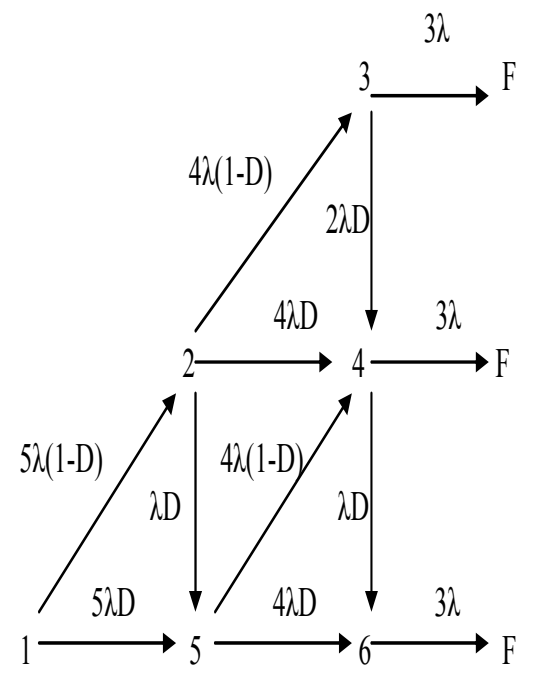

Figure 5. Markov Model For A Fiveplex

The Differential equations for the fiveplex in figure 5 are

$$
\begin{aligned}
\mathrm{p}_{1}^{\prime}= & -5 \lambda \mathrm{p}_{1} \\
\mathrm{p}_{2}^{\prime}= & 5 \lambda(1-\mathrm{D}) \mathrm{p}_{1}-(4 \lambda+2 \lambda D) \mathrm{p}_{2} \\
\mathrm{p}_{3}^{\prime}= & 4 \lambda(1-\mathrm{D}) \mathrm{p}_{2}-(3 \lambda+\lambda D) \mathrm{p}_{3} \\
\mathrm{p}_{4}^{\prime}= & 4 \lambda D \mathrm{p}_{2}+2 \lambda D \mathrm{p}_{3}+4 \lambda(1-\mathrm{D}) \mathrm{p}_{5} \\
& \quad-(3 \lambda+\lambda D) \mathrm{p}_{4} \\
\mathrm{p}_{5}^{\prime}= & 5 \lambda D \mathrm{p}_{1}+\lambda D \mathrm{p}_{2}-4 \lambda \mathrm{p}_{5} \\
\mathrm{p}_{6}^{\prime}= & \lambda D \mathrm{p}_{4}+4 \lambda D \mathrm{p}_{5}-3 \lambda \mathrm{p}_{6} \\
\mathrm{~F}^{\prime}= & 3 \lambda \mathrm{p}_{3}+3 \lambda \mathrm{p}_{4}+3 \lambda \mathrm{p}_{6}
\end{aligned}
$$

The initial conditions at time zero are

$$
\begin{aligned}
& \mathrm{p}_{1}=1 \\
& \mathrm{p}_{2}=\mathrm{p}_{3}=\mathrm{p}_{4}=\mathrm{p}_{5}=\mathrm{p}_{6}=0 \\
& \mathrm{~F}=0
\end{aligned}
$$

When regular maintenance is performed all components identified as faulty are replaced by good components. The initial conditions for the next operating period are

$$
\begin{aligned}
& \mathrm{p}_{1}=\mathrm{p}_{1}+\mathrm{p}_{5}+\mathrm{p}_{6} \\
& \mathrm{p}_{2}=\mathrm{p}_{2}+\mathrm{p}_{4} \\
& \mathrm{p}_{3}=\mathrm{p}_{3} \\
& \mathrm{p}_{4}=\mathrm{p}_{5}=\mathrm{p}_{6}=0 \\
& \mathrm{~F}=\mathrm{F}
\end{aligned}
$$

\section{Tables for Regular Maintenance}

In the tables below, bold (and blue if color appears in this version) print indicates the entries that meet the requirement of less than a 0.01 chance of failure during the ten-year operating period.

The first six tables give the probability of failure during the ten year operating period for the four systems where the component failure rate is 1e-4 per hour.

Table 1. Threeplex; $\lambda=1 \mathrm{e}-4 / \mathrm{hr}$

\begin{tabular}{|l|l|l|l|l|}
\hline $\begin{array}{l}\text { Diagnostic } \\
\text { Maint Per }\end{array}$ & 1.0 & 0.999 & 0.99 & 0.9 \\
\hline 1 day & $6.1 \mathrm{e}-2$ & $7.6 \mathrm{e}-2$ & $2.1 \mathrm{e}-1$ & $8.2 \mathrm{e}-1$ \\
\hline 7 days & $3.5 \mathrm{e}-1$ & $3.6 \mathrm{e}-1$ & $4.5 \mathrm{e}-1$ & $8.7 \mathrm{e}-1$ \\
\hline 30 days & $8.2 \mathrm{e}-1$ & $8.2 \mathrm{e}-1$ & $8.4 \mathrm{e}-1$ & $9.5 \mathrm{e}-1$ \\
\hline 365 days & $9.9 \mathrm{e}-1$ & $9.9 \mathrm{e}-1$ & $9.9 \mathrm{e}-1$ & $9.9 \mathrm{e}-1$ \\
\hline
\end{tabular}

Table 2. Pessimistic Double-Dual;

\begin{tabular}{|l|l|l|l|l|}
\hline $\begin{array}{l}\text { Diagnostic } \\
\text { Maint Per }\end{array}$ & 1.0 & 0.999 & 0.99 & 0.9 \\
\hline 1 day & $8.0 \mathrm{e}-2$ & $9.6 \mathrm{e}-2$ & $8.4 \mathrm{e}-1$ & $8.4 \mathrm{e}-1$ \\
\hline 7 days & $4.3 \mathrm{e}-1$ & $4.4 \mathrm{e}-1$ & $8.9 \mathrm{e}-1$ & $8.9 \mathrm{e}-1$ \\
\hline 30 days & $8.9 \mathrm{e}-1$ & $8.9 \mathrm{e}-1$ & $9.7 \mathrm{e}-1$ & $9.7 \mathrm{e}-1$ \\
\hline 365 days & 1.0 & 1.0 & 1.0 & 1.0 \\
\hline
\end{tabular}


Table 3. Optimistic Double-Dual;

$\lambda=1 \mathrm{e}-4 / \mathrm{hr}$

\begin{tabular}{|l|l|l|l|l|}
\hline Diagnostic & 1.0 & 0.999 & 0.99 & 0.9 \\
$\begin{array}{l}\text { Maint } \\
\text { Period }\end{array}$ & & & & \\
\hline 1 day & $8.0 \mathrm{e}-2$ & $9,6 \mathrm{e}-2$ & $2.2 \mathrm{e}-1$ & $8.3 \mathrm{e}-1$ \\
\hline 7 days & $4.3 \mathrm{e}-1$ & $4.4 \mathrm{e}-1$ & $5.2 \mathrm{e}-1$ & $8.9 \mathrm{e}-1$ \\
\hline 30 days & $8.9 \mathrm{e}-1$ & $8.9 \mathrm{e}-1$ & $9.0 \mathrm{e}-1$ & $9.7 \mathrm{e}-1$ \\
\hline 365 days & 1.0 & 1.0 & 1.0 & 1.0 \\
\hline
\end{tabular}

Table 4: Fourplex; $\lambda=1 \mathrm{e}-4 / \mathrm{hr} ; \delta=1000 / \mathrm{hr}$

\begin{tabular}{|l|l|l|l|l|}
\hline $\begin{array}{l}\text { Diagnostic } \\
\text { Maint Per }\end{array}$ & 1.0 & 0.999 & 0.99 & 0.9 \\
\hline 1 day & $\mathbf{2 . 1 e - 4}$ & $2.5 \mathrm{e}-2$ & $2.3 \mathrm{e}-1$ & $9.2 \mathrm{e}-1$ \\
\hline 7 days & $\mathbf{9 . 5 e - 3}$ & $3.4 \mathrm{e}-2$ & $2.3 \mathrm{e}-1$ & $9.2 \mathrm{e}-1$ \\
\hline 30 days & $1.4 \mathrm{e}-1$ & $1.6 \mathrm{e}-1$ & $3.3 \mathrm{e}-1$ & $9.3 \mathrm{e}-1$ \\
\hline 365 days & $9.9 \mathrm{e}-1$ & $9.9 \mathrm{e}-1$ & $9.9 \mathrm{e}-1$ & $9.9 \mathrm{e}-1$ \\
\hline
\end{tabular}

Table 5: Fourplex; $\lambda=1 \mathrm{e}-4 / \mathrm{hr} ; \delta=10,000 / \mathrm{hr}$

\begin{tabular}{|l|l|l|l|l|}
\hline $\begin{array}{l}\text { Diagnostic } \\
\text { Maint Per }\end{array}$ & 1.0 & 0.999 & 0.99 & 0.9 \\
\hline 1 day & $\mathbf{2 . 0 e - 4}$ & $2.5 \mathrm{e}-2$ & $2.2 \mathrm{e}-1$ & $9.2 \mathrm{e}-1$ \\
\hline 7 days & $\mathbf{9 . 5 e - 3}$ & $3.4 \mathrm{e}-2$ & $2.3 \mathrm{e}-1$ & $9.2 \mathrm{e}-1$ \\
\hline 30 days & $1.4 \mathrm{e}-1$ & $1.6 \mathrm{e}-1$ & $3.3 \mathrm{e}-1$ & $9.3 \mathrm{e}-1$ \\
\hline 365 days & $9.9 \mathrm{e}-1$ & $9.9 \mathrm{e}-1$ & $9.9 \mathrm{e}-1$ & $9.9 \mathrm{e}-1$ \\
\hline
\end{tabular}

Table 6. Fiveplex; $\lambda=1 \mathrm{e}-4 / \mathrm{hr}$

\begin{tabular}{|l|l|l|l|l|}
\hline $\begin{array}{l}\text { Diagnostic } \\
\text { Maint Per }\end{array}$ & 1.0 & 0.999 & 0.99 & 0.9 \\
\hline 1 day & $\mathbf{5 . 0 e - 4}$ & $\mathbf{1 . 1 e - 3}$ & $1.4 \mathrm{e}-2$ & $4.7 \mathrm{e}-1$ \\
\hline 7 days & $2.3 \mathrm{e}-2$ & $2.6 \mathrm{e}-2$ & $6.1 \mathrm{e}-2$ & $5.5 \mathrm{e}-1$ \\
\hline 30 days & $3 . \mathrm{e}-1$ & $3.1 \mathrm{e}-1$ & $3.7 \mathrm{e}-1$ & $7.7 \mathrm{e}-1$ \\
\hline 365 days & $9.9 \mathrm{e}-1$ & $9.9 \mathrm{e}-1$ & $9.9 \mathrm{e}-1$ & $9.9 \mathrm{e}-1$ \\
\hline
\end{tabular}

The next six tables give the probability of failure during with a failure rate of 1 e-5 per hour.

Table 7. Threeplex; $\lambda=1 \mathrm{e}-5 / \mathrm{hr}$

\begin{tabular}{|l|l|l|l|l|}
\hline $\begin{array}{l}\text { Diagnostic } \\
\text { Maint Per }\end{array}$ & 1.0 & 0.999 & 0.99 & 0.9 \\
\hline 1 day & $\mathbf{6 . 3 e - 4}$ & $\mathbf{1 . 8 e - 3}$ & $1.2 \mathrm{e}-2$ & $1.0 \mathrm{e}-1$ \\
\hline $\mathbf{7}$ days & $\mathbf{4 . 4 e - 3}$ & $\mathbf{5 . 6 e - 3}$ & $1.6 \mathrm{e}-2$ & $1.1 \mathrm{e}-1$ \\
\hline 30 days & $1.8 \mathrm{e}-2$ & $1.9 \mathrm{e}-2$ & $2.9 \mathrm{e}-2$ & $1.2 \mathrm{e}-1$ \\
\hline 365 days & $1.8 \mathrm{e}-1$ & $1.9 \mathrm{e}-1$ & $1.8 \mathrm{e}-1$ & $2.4 \mathrm{e}-1$ \\
\hline
\end{tabular}

Table 8. Pessimistic Double-Dual; $\lambda=1 \mathrm{e}-5 / \mathrm{hr}$

\begin{tabular}{|l|l|l|l|l|}
\hline $\begin{array}{l}\text { Diagnostic } \\
\text { Maint Per }\end{array}$ & 1.0 & 0.999 & 0.99 & 0.9 \\
\hline 1 day & $\mathbf{8 . 4 e - 4}$ & $\mathbf{2 . 1 e - 3}$ & $1.3 \mathrm{e}-2$ & $1.2 \mathrm{e}-1$ \\
\hline 7 days & $\mathbf{5 . 8 e - 3}$ & $\mathbf{7 . 1 e - 3}$ & $1.8 \mathrm{e}-2$ & $1.3 \mathrm{e}-1$ \\
\hline 30 days & $2.4 \mathrm{e}-2$ & $2.5 \mathrm{e}-2$ & $3.6 \mathrm{e}-2$ & $1.4 \mathrm{e}-1$ \\
\hline 365 days & $2.3 \mathrm{e}-1$ & $2.3 \mathrm{e}-1$ & $2.4 \mathrm{e}-1$ & $2.9 \mathrm{e}-1$ \\
\hline
\end{tabular}

Table 9. Optimistic Double-Dual; $\lambda=1 \mathrm{e}-5 / \mathrm{hr}$

\begin{tabular}{|l|l|l|l|l|}
\hline $\begin{array}{l}\text { Diagnostic } \\
\text { Maint Per }\end{array}$ & 1.0 & 0.999 & 0.99 & 0.9 \\
\hline 1 day & $\mathbf{8 . 4 e - 4}$ & $\mathbf{2 . 1 e - 3}$ & $1.3 \mathrm{e}-2$ & $1.2 \mathrm{e}-1$ \\
\hline 7 days & $\mathbf{5 . 8 e - 3}$ & $\mathbf{7 . 1 e - 3}$ & $1.8 \mathrm{e}-2$ & $1.2 \mathrm{e}-1$ \\
\hline 30 days & $2.4 \mathrm{e}-2$ & $2.5 \mathrm{e}-2$ & $3.6 \mathrm{e}-2$ & $1.3 \mathrm{e}-1$ \\
\hline 365 days & $2.3 \mathrm{e}-1$ & $2.3 \mathrm{e}-1$ & $2.4 \mathrm{e}-1$ & $2.9 \mathrm{e}-1$ \\
\hline
\end{tabular}


Table 10. Fourplex; $\lambda=1 \mathrm{e}-5 / \mathrm{hr} ; \delta=1000 / \mathrm{hr}$

\begin{tabular}{|l|l|l|l|l|}
\hline $\begin{array}{l}\text { Diagnostic } \\
\text { Maint Per }\end{array}$ & 1.0 & 0.999 & 0.99 & \multicolumn{1}{l|}{0} \\
\hline 1 day & $\mathbf{3 . 1 e - 7}$ & $\mathbf{1 . 9 e - 3}$ & $1.8 \mathrm{e}-2$ & $1.7 \mathrm{e}-1$ \\
\hline $\mathbf{7}$ days & $\mathbf{9 . 9 e - 6}$ & $\mathbf{1 . 9 e - 3}$ & $1.9 \mathrm{e}-2$ & $1.7 \mathrm{e}-1$ \\
\hline 30 days & $\mathbf{1 . 8 e - 4}$ & $\mathbf{2 . 1 e - 3}$ & $1.9 \mathrm{e}-2$ & $1.7 \mathrm{e}-1$ \\
\hline 365 days & $2.2 \mathrm{e}-2$ & $2.4 \mathrm{e}-2$ & $3.9 \mathrm{e}-2$ & $1.8 \mathrm{e}-1$ \\
\hline
\end{tabular}

Table 11. Fourplex; $\lambda=1 \mathrm{e}-5 / \mathrm{hr} ; \delta=10,000 / \mathrm{hr}$

\begin{tabular}{|l|l|l|l|l|}
\hline $\begin{array}{l}\text { Diagnostic } \\
\text { Maint Per }\end{array}$ & 1.0 & 0.999 & 0.99 & 0.9 \\
\hline 1 day & $\mathbf{2 . 1 e - 7}$ & $\mathbf{1 . 8 e - 3}$ & $1.8 \mathrm{e}-2$ & $1.7 \mathrm{e}-1$ \\
\hline 7 days & $\mathbf{9 . 8 e - 6}$ & $\mathbf{1 . 9 e - 3}$ & $1.8 \mathrm{e}-2$ & $1.7 \mathrm{e}-1$ \\
\hline 30 days & $\mathbf{1 . 7 e - 4}$ & $\mathbf{2 . 1 e - 3}$ & $1.9 \mathrm{e}-2$ & $1.7 \mathrm{e}-1$ \\
\hline 365 days & $2.2 \mathrm{e}-2$ & $2.4 \mathrm{e}-2$ & $3.9 \mathrm{e}-2$ & $1.7 \mathrm{e}-1$ \\
\hline
\end{tabular}

Table 12. Fiveplex; $\lambda=1 \mathrm{e}-5 / \mathrm{hr}$

\begin{tabular}{|l|l|l|l|l|}
\hline $\begin{array}{l}\text { Diag } \\
\text { Maint Per }\end{array}$ & 1.0 & 0.999 & 0.99 & 0.9 \\
\hline 1 day & $\mathbf{5 . 0 e - 7}$ & $\mathbf{4 . 9 e - 6}$ & $\mathbf{2 . 5 e - 4}$ & $2.1 \mathrm{e}-2$ \\
\hline $\mathbf{7}$ days & $\mathbf{2 . 4 e - 5}$ & $\mathbf{4 . 1 e - 5}$ & $\mathbf{3 . 9 e - 4}$ & $2.1 \mathrm{e}-2$ \\
\hline 30 days & $\mathbf{4 . 4 e - 4}$ & $\mathbf{5 . 0 e - 4}$ & $\mathbf{1 . 2 e - 3}$ & $2.5 \mathrm{e}-2$ \\
\hline 365 day & $5.1 \mathrm{e}-2$ & $5.1 \mathrm{e}-2$ & $5.4 \mathrm{e}-2$ & $9.7 \mathrm{e}-2$ \\
\hline
\end{tabular}

\section{Discussion of Results for Regular Maintenance}

For the systems where the component failure rate is 1e-4 per hour, the results are dismal. It is difficult to overcome the liability of expected component life-time being much smaller than system operating time.

Neither the threeplex nor the double-duals have successful entries. Both cases of the fourplex have two successful entries, but these entries require a $100 \%$ diagnostic level. A faster recovery rate makes little contribution. The fiveplex has two successful entries. The entries require $100 \%$ and
$99.9 \%$ diagnostics. Both require daily regular maintenance.

The results for the pessimistic and optimistic models of the double-dual are nearly the same, indicating that the pessimistic model can be used and there is no reason for additional experiments to decide between the two models.

The last four tables in the previous section give the results where the component failure rate is $1 \mathrm{e}-5$ per hour.

All the architectures have successful entries for this component failure rate.

For the threeplex, the diagnostic level can drop to $99.9 \%$, and the regular-maintenance schedule can be reduced to weekly. The same is true for the double-dual. For the fourplexes, the diagnostic level can drop to $99.9 \%$. Once again, a faster recovery has only a small effect, but the reconfiguration makes the system more efficient in with respect to hardware, and the regularmaintenance schedule can be reduced to monthly. For the fiveplex, the diagnostic level can drop to $99 \%$ and the regular-maintenance schedule can be reduced to monthly.

The drop in diagnostic requirement for the fiveplex is the significant result. A high diagnostic level requires a careful and stringent design.

For these systems, the most important factor is failure rate of the components.

\section{Tables for Preventive Maintenance}

This section presents the results when the old system is replaced by a new system on a periodic basis - preventive maintenance. As before, the tables give the probability of system failure during the ten year operating period.

The tables do not list the results for a diagnostic level of $100 \%$ since in this case, because the components are not wearing out, regular maintenance yields a system as good-as-new, and hence, it is equivalent to preventive maintenance.

For these systems, there is no regular maintenance at a one year interval since such regular maintenance would come close to the preventive maintenance schedule. 
Italics (and blue if this version supports color) indicate the entries where the system met the reliability requirement without preventive maintenance. Bold (and magenta if this version supports color) indicates the entries where preventive maintenance extends the system reliability. The first six tables consider systems with a component failure rate of 1e-4 per hour; the second six tables consider systems with a component failure rate of 1e-5 per hour.

Once again, there are no entries for a diagnostic level of 1.0 since regular maintenance is equivalent to preventative maintenance in this case.

Table 13. Threeplex; $\lambda=1 \mathrm{e}-4 / \mathrm{hour}$

\begin{tabular}{|l|l|l|l|l|}
\hline $\begin{array}{l}\text { Diag } \\
\text { Level }\end{array}$ & $\begin{array}{l}\text { Regular } \\
\text { Maint } \\
\text { Period }\end{array}$ & $\begin{array}{l}\text { System } \\
\text { replaced } \\
\text { every } \\
1 \text { year }\end{array}$ & $\begin{array}{l}\text { System } \\
\text { replaced } \\
\text { every } \\
2 \text { years }\end{array}$ & $\begin{array}{l}\text { System } \\
\text { replaced } \\
\text { every } \\
5 \text { years }\end{array}$ \\
\hline 0.999 & 1 day & $7.1 \mathrm{e}-2$ & $7.4 \mathrm{e}-2$ & $7.5 \mathrm{e}-2$ \\
\hline 0.999 & 7 days & $3.5 \mathrm{e}-1$ & $3.5 \mathrm{e}-1$ & $3.5 \mathrm{e}-1$ \\
\hline 0.999 & 30 days & $8.1 \mathrm{e}-1$ & $8.1 \mathrm{e}-1$ & $8.1 \mathrm{e}-1$ \\
\hline & & & & \\
\hline 0.99 & 1 day & $1.6 \mathrm{e}-1$ & $1.8 \mathrm{e}-1$ & $2.0 \mathrm{e}-1$ \\
\hline 0.99 & 7 days & $4.1 \mathrm{e}-1$ & $4.2 \mathrm{e}-1$ & $4.4 \mathrm{e}-1$ \\
\hline 0.99 & 30 days & $8.2 \mathrm{e}-1$ & $8.3 \mathrm{e}-1$ & $8.4 \mathrm{e}-1$ \\
\hline & & & & \\
\hline 0.9 & 1 day & $6.9 \mathrm{e}-1$ & $7.6 \mathrm{e}-1$ & $8.1 \mathrm{e}-1$ \\
\hline 0.9 & 7 days & $7.7 \mathrm{e}-1$ & $8.2 \mathrm{e}-1$ & $8.6 \mathrm{e}-1$ \\
\hline 0.9 & 30 days & $9.1 \mathrm{e}-1$ & $9.3 \mathrm{e}-1$ & $9.5 \mathrm{e}-1$ \\
\hline
\end{tabular}

Table 14. Pessimistic Double-Dual; $\lambda=1 \mathrm{e}-4$ /hour

\begin{tabular}{|l|l|l|l|l|}
\hline $\begin{array}{l}\text { Diag } \\
\text { Level }\end{array}$ & $\begin{array}{l}\text { Regular } \\
\text { Maint } \\
\text { Period }\end{array}$ & $\begin{array}{l}\text { System } \\
\text { replaced } \\
\text { every } \\
1 \text { year }\end{array}$ & $\begin{array}{l}\text { System } \\
\text { replaced } \\
\text { every } \\
2 \text { years }\end{array}$ & $\begin{array}{l}\text { System } \\
\text { replaced } \\
\text { every } \\
5 \text { years }\end{array}$ \\
\hline 0.999 & 1 day & $9.2 \mathrm{e}-2$ & $9.4 \mathrm{e}-2$ & $9.5 \mathrm{e}-2$ \\
\hline 0.999 & 7 days & $4.4 \mathrm{e}-1$ & $4.4 \mathrm{e}-1$ & $4.4 \mathrm{e}-1$ \\
\hline 0.999 & 30 days & $8.9 \mathrm{e}-1$ & $8.9 \mathrm{e}-1$ & $8.9 \mathrm{e}-1$ \\
\hline & & & & \\
\hline 0.99 & 1 day & $1.9 \mathrm{e}-1$ & $2.1 \mathrm{e}-1$ & $2.2 \mathrm{e}-1$ \\
\hline 0.99 & 7 days & $5.0 \mathrm{e}-1$ & $5.1 \mathrm{e}-1$ & $5.2 \mathrm{e}-1$ \\
\hline 0.99 & 30 days & $9.0 \mathrm{e}-1$ & $9.0 \mathrm{e}-1$ & $9.0 \mathrm{e}-1$ \\
\hline & & & & \\
\hline 0.9 & 1 day & $7.5 \mathrm{e}-1$ & $8.0 \mathrm{e}-1$ & $8.3 \mathrm{e}-1$ \\
\hline 0.9 & 7 days & $8.3 \mathrm{e}-1$ & $8.8 \mathrm{e}-1$ & $8.8 \mathrm{e}-1$ \\
\hline 0.9 & 30 days & $9.5 \mathrm{e}-1$ & $9.6 \mathrm{e}-1$ & $9.7 \mathrm{e}-1$ \\
\hline
\end{tabular}

Table 15. Optimistic Double-Dual; $\lambda=1 \mathrm{e}-4 /$ hour

\begin{tabular}{|l|l|l|l|l|}
\hline $\begin{array}{l}\text { Diag } \\
\text { Level }\end{array}$ & $\begin{array}{l}\text { Regular } \\
\text { Maint } \\
\text { Period }\end{array}$ & $\begin{array}{l}\text { System } \\
\text { replaced } \\
\text { every } \\
1 \text { year }\end{array}$ & $\begin{array}{l}\text { System } \\
\text { replaced } \\
\text { every } \\
2 \text { years }\end{array}$ & $\begin{array}{l}\text { System } \\
\text { replaced } \\
\text { every } \\
5 \text { years }\end{array}$ \\
\hline 0.999 & 1 day & $9.2 \mathrm{e}-2$ & $9.4 \mathrm{e}-2$ & $9.5 \mathrm{e}-2$ \\
\hline 0.999 & 7 days & $4.4 \mathrm{e}-1$ & $4.4 \mathrm{e}-1$ & $4.4 \mathrm{e}-1$ \\
\hline 0.999 & 30 days & $8.9 \mathrm{e}-1$ & $8.9 \mathrm{e}-1$ & $8.9 \mathrm{e}-1$ \\
\hline & & & & \\
\hline 0.99 & 1 day & $1.9 \mathrm{e}-1$ & $2.1 \mathrm{e}-1$ & $2.2 \mathrm{e}-1$ \\
\hline 0.99 & 7 days & $5.0 \mathrm{e}-1$ & $5.1 \mathrm{e}-1$ & $5.2 \mathrm{e}-1$ \\
\hline 0.99 & 30 days & $9.0 \mathrm{e}-1$ & $9.0 \mathrm{e}-1$ & $9.0 \mathrm{e}-1$ \\
\hline & & & & \\
\hline 0.9 & 1 day & $7.3 \mathrm{e}-1$ & $7.9 \mathrm{e}-1$ & $8.2 \mathrm{e}-1$ \\
\hline 0.9 & 7 days & $8.2 \mathrm{e}-1$ & $8.6 \mathrm{e}-1$ & $8.8 \mathrm{e}-1$ \\
\hline 0.9 & 30 days & $9.5 \mathrm{e}-1$ & $9.6 \mathrm{e}-1$ & $9.7 \mathrm{e}-1$ \\
\hline
\end{tabular}


Table 16. Fourplex; $\lambda=1 \mathrm{e}-4 /$ hour; $\delta=1000 /$ hour

\begin{tabular}{|l|l|l|l|l|}
\hline $\begin{array}{l}\text { Diag } \\
\text { Level }\end{array}$ & $\begin{array}{l}\text { Regular } \\
\text { Maint } \\
\text { Period }\end{array}$ & $\begin{array}{l}\text { System } \\
\text { replaced } \\
\text { every } \\
1 \text { year }\end{array}$ & $\begin{array}{l}\text { System } \\
\text { replaced } \\
\text { every } \\
2 \text { years }\end{array}$ & $\begin{array}{l}\text { System } \\
\text { replaced } \\
\text { every } \\
5 \text { years }\end{array}$ \\
\hline 0.999 & 1 day & $1.9 \mathrm{e}-2$ & $2.2 \mathrm{e}-2$ & $2.4 \mathrm{e}-2$ \\
\hline 0.999 & 7 days & $2.7 \mathrm{e}-2$ & $3.1 \mathrm{e}-2$ & $3.3 \mathrm{e}-2$ \\
\hline 0.999 & 30 days & $1.5 \mathrm{e}-1$ & $1.5 \mathrm{e}-1$ & $1.6 \mathrm{e}-1$ \\
\hline & & & & \\
\hline 0.99 & 1 day & $1.7 \mathrm{e}-1$ & $2.0 \mathrm{e}-1$ & $2.1 \mathrm{e}-1$ \\
\hline 0.99 & 7 days & $1.7 \mathrm{e}-1$ & $2.0 \mathrm{e}-1$ & $2.2 \mathrm{e}-1$ \\
\hline 0.99 & 30 days & $2.8 \mathrm{e}-1$ & $3.0 \mathrm{e}-1$ & $3.2 \mathrm{e}-1$ \\
\hline & & & & \\
\hline 0.9 & 1 day & $8.4 \mathrm{e}-1$ & $8.9 \mathrm{e}-1$ & $9.1 \mathrm{e}-1$ \\
\hline 0.9 & 7 days & $8.4 \mathrm{e}-1$ & $8.9 \mathrm{e}-1$ & $9.1 \mathrm{e}-1$ \\
\hline 0.9 & 30 days & $8.5 \mathrm{e}-1$ & $8.9 \mathrm{e}-1$ & $9.2 \mathrm{e}-1$ \\
\hline
\end{tabular}

Table 17. Fourplex; $\lambda=1 \mathrm{e}-4 /$ hour; $\delta=10000 /$ hour

\begin{tabular}{|l|l|l|l|l|}
\hline Diag & Regular \\
Level & $\begin{array}{l}\text { Maint } \\
\text { replaced } \\
\text { every } \\
1 \text { year }\end{array}$ & $\begin{array}{l}\text { System } \\
\text { replaced } \\
\text { every } \\
2 \text { years }\end{array}$ & $\begin{array}{l}\text { System } \\
\text { replaced } \\
\text { every } \\
5 \text { years }\end{array}$ \\
\hline 0.999 & 1 day & $1.8 \mathrm{e}-2$ & $2.2 \mathrm{e}-2$ & $2.4 \mathrm{e}-2$ \\
\hline 0.999 & 7 days & $2.7 \mathrm{e}-2$ & $3.1 \mathrm{e}-2$ & $3.3 \mathrm{e}-2$ \\
\hline 0.999 & 30 days & $1.5 \mathrm{e}-1$ & $1.5 \mathrm{e}-1$ & $1.6 \mathrm{e}-1$ \\
\hline & & & & \\
\hline 0.99 & 1 day & $1.7 \mathrm{e}-1$ & $2.0 \mathrm{e}-1$ & $2.1 \mathrm{e}-1$ \\
\hline 0.99 & 7 days & $1.8 \mathrm{e}-1$ & $2.0 \mathrm{e}-1$ & $2.2 \mathrm{e}-1$ \\
\hline 0.99 & 30 days & $2.7 \mathrm{e}-1$ & $3.0 \mathrm{e}-1$ & $3.2 \mathrm{e}-1$ \\
\hline & & & & \\
\hline 0.9 & 1 day & $8.4 \mathrm{e}-1$ & $8.9 \mathrm{e}-1$ & $9.1 \mathrm{e}-1$ \\
\hline 0.9 & 7 days & $8.4 \mathrm{e}-1$ & $8.9 \mathrm{e}-1$ & $9.1 \mathrm{e}-1$ \\
\hline 0.9 & 30 days & $8.5 \mathrm{e}-1$ & $8.9 \mathrm{e}-1$ & $9.2 \mathrm{e}-1$ \\
\hline
\end{tabular}

Table 18. Fiveplex; $\lambda=1 \mathrm{e}-4 /$ hour

\begin{tabular}{|l|l|l|l|l|}
\hline $\begin{array}{l}\text { Diag } \\
\text { Level }\end{array}$ & $\begin{array}{l}\text { Regular } \\
\text { Maint } \\
\text { Period }\end{array}$ & $\begin{array}{l}\text { System } \\
\text { replaced } \\
\text { every } \\
1 \text { year }\end{array}$ & $\begin{array}{l}\text { System } \\
\text { replaced } \\
\text { every } \\
2 \text { years }\end{array}$ & $\begin{array}{l}\text { System } \\
\text { replaced } \\
\text { every } \\
5 \text { years }\end{array}$ \\
\hline 0.999 & 1 day & $7.3 e-4$ & $8.7 e-4$ & $1.0 e-3$ \\
\hline 0.999 & 7 days & $2.4 \mathrm{e}-2$ & $2.5 \mathrm{e}-2$ & $2.6 \mathrm{e}-2$ \\
\hline 0.999 & 30 days & $3.0 \mathrm{e}-1$ & $3.0 \mathrm{e}-1$ & $3.1 \mathrm{e}-1$ \\
\hline & & & & \\
\hline 0.99 & 1 day & $\mathbf{4 . 8 e - 3}$ & $\mathbf{8 . 0 e}-3$ & $1.2 \mathrm{e}-2$ \\
\hline 0.99 & 7 days & $3.7 \mathrm{e}-2$ & $4.6 \mathrm{e}-2$ & $5.6 \mathrm{e}-2$ \\
\hline 0.99 & 30 days & $3.3 \mathrm{e}-1$ & $3.4 \mathrm{e}-1$ & $3.6 \mathrm{e}-1$ \\
\hline & & & & \\
\hline 0.9 & 1 day & $2.0 \mathrm{e}-1$ & $3.2 \mathrm{e}-1$ & $4.3 \mathrm{e}-1$ \\
\hline 0.9 & 7 days & $2.7 \mathrm{e}-1$ & $4.0 \mathrm{e}-1$ & $5.2 \mathrm{e}-1$ \\
\hline 0.9 & 30 days & $5.6 \mathrm{e}-1$ & $6.6 \mathrm{e}-1$ & $7.5 \mathrm{e}-1$ \\
\hline
\end{tabular}

Table 19. Threeplex; $\lambda=1 \mathrm{e}-5 / \mathrm{hour}$

\begin{tabular}{|l|l|l|l|l|}
\hline $\begin{array}{l}\text { Diag } \\
\text { Level }\end{array}$ & $\begin{array}{l}\text { Regular } \\
\text { Maint } \\
\text { Period }\end{array}$ & $\begin{array}{l}\text { System } \\
\text { replaced } \\
\text { every } \\
1 \text { year }\end{array}$ & $\begin{array}{l}\text { System } \\
\text { replaced } \\
\text { every } \\
2 \text { years }\end{array}$ & $\begin{array}{l}\text { System } \\
\text { replaced } \\
\text { every } \\
5 \text { years }\end{array}$ \\
\hline 0.999 & 1 day & $8.6 e-4$ & $1.0 e-3$ & $1.4 e-3$ \\
\hline 0.999 & 7 days & $4.5 e-3$ & $4.7 e-3$ & $5.1 e-3$ \\
\hline 0.999 & 30 days & $1.8 \mathrm{e}-2$ & $1.8 \mathrm{e}-2$ & $1.9 \mathrm{e}-2$ \\
\hline 0.99 & 1 day & $\mathbf{2 . 7 e - 3}$ & $\mathbf{4 . 5 e - 3}$ & $\mathbf{8 . 3 e - 3}$ \\
\hline 0.99 & 7 days & $\mathbf{6 . 4 e - 3}$ & $\mathbf{8 . 1 e - 3}$ & $1.2 \mathrm{e}-2$ \\
\hline 0.99 & 30 days & $2.0 \mathrm{e}-2$ & $2.1 \mathrm{e}-2$ & $2.5 \mathrm{e}-2$ \\
\hline & & & & \\
\hline 0.9 & 1 day & $2.1 \mathrm{e}-2$ & $3.8 \mathrm{e}-2$ & $7.4 \mathrm{e}-2$ \\
\hline 0.9 & 7 days & $2.4 \mathrm{e}-2$ & $4.1 \mathrm{e}-2$ & $7.7 \mathrm{e}-2$ \\
\hline 0.9 & 30 days & $3.6 \mathrm{e}-2$ & $5.2 \mathrm{e}-2$ & $8.8 \mathrm{e}-2$ \\
\hline
\end{tabular}


Table 20. Pessimistic Double-Dual; $\lambda=1 \mathrm{e}-5 /$ hour

\begin{tabular}{|l|l|l|l|l|}
\hline $\begin{array}{l}\text { Diag } \\
\text { Level }\end{array}$ & $\begin{array}{l}\text { Regular } \\
\text { Maint } \\
\text { Period }\end{array}$ & $\begin{array}{l}\text { System } \\
\text { replaced } \\
\text { every } \\
1 \text { year }\end{array}$ & $\begin{array}{l}\text { System } \\
\text { replaced } \\
\text { every } \\
2 \text { years }\end{array}$ & $\begin{array}{l}\text { System } \\
\text { replaced } \\
\text { every } \\
5 \text { years }\end{array}$ \\
\hline 0.999 & 1 day & $1.1 e-3$ & $1.3 e-3$ & $1.8 e-3$ \\
\hline 0.999 & 7 days & $6.1 e-3$ & $6.3 e-3$ & $6.8 e-3$ \\
\hline 0.999 & 30 days & $2.4 \mathrm{e}-2$ & $2.5 \mathrm{e}-2$ & $2.5 \mathrm{e}-2$ \\
\hline & & & & \\
\hline 0.99 & 1 day & $\mathbf{3 . 6 e - 3}$ & $\mathbf{5 . 8 e - 3}$ & $\mathbf{1 . 0 e - 2}$ \\
\hline 0.99 & 7 days & $\mathbf{8 . 5 e - 3}$ & $1.1 \mathrm{e}-2$ & $1.5 \mathrm{e}-2$ \\
\hline 0.99 & 30 days & $2.7 \mathrm{e}-2$ & $2.9 \mathrm{e}-2$ & $3.3 \mathrm{e}-2$ \\
\hline & & & & \\
\hline 0.9 & 1 day & $2.9 \mathrm{e}-2$ & $5.0 \mathrm{e}-2$ & $9.1 \mathrm{e}-2$ \\
\hline 0.9 & 7 days & $3.3 \mathrm{e}-2$ & $5.4 \mathrm{e}-2$ & $9.5 \mathrm{e}-2$ \\
\hline 0.9 & 30 days & $4.8 \mathrm{e}-2$ & $6.9 \mathrm{e}-2$ & $1.1 \mathrm{e}-1$ \\
\hline
\end{tabular}

Table 21. Optimistic Double-Dual; $\lambda=1 \mathrm{e}-5 / \mathrm{hour}$

\begin{tabular}{|l|l|l|l|l|}
\hline $\begin{array}{l}\text { Diag } \\
\text { Level }\end{array}$ & $\begin{array}{l}\text { Regular } \\
\text { Maint } \\
\text { Period }\end{array}$ & $\begin{array}{l}\text { System } \\
\text { replaced } \\
\text { every } \\
1 \text { year }\end{array}$ & $\begin{array}{l}\text { System } \\
\text { replaced } \\
\text { every } \\
2 \text { years }\end{array}$ & $\begin{array}{l}\text { System } \\
\text { replaced } \\
\text { every } \\
5 \text { years }\end{array}$ \\
\hline 0.999 & 1 day & $1.1 e-3$ & $1.3 e-3$ & $1.8 e-3$ \\
\hline 0.999 & 7 days & $6.1 e-3$ & $6.3 e-3$ & $6.8 e-3$ \\
\hline 0.999 & 30 days & $2.4 \mathrm{e}-2$ & $2.5 \mathrm{e}-2$ & $2.5 \mathrm{e}-2$ \\
\hline & & & & \\
\hline 0.99 & 1 day & $\mathbf{3 . 6 e - 3}$ & $\mathbf{5 . 7 e - 3}$ & $\mathbf{1 . 0 e - 2}$ \\
\hline 0.99 & 7 days & $\mathbf{8 . 5 e - 3}$ & $1.1 \mathrm{e}-2$ & $1.5 \mathrm{e}-2$ \\
\hline 0.99 & 30 days & $2.7 \mathrm{e}-2$ & $2.9 \mathrm{e}-2$ & $3.3 \mathrm{e}-2$ \\
\hline & & & & \\
\hline 0.9 & 1 day & $2.8 \mathrm{e}-2$ & $4.8 \mathrm{e}-2$ & $8.8 \mathrm{e}-2$ \\
\hline 0.9 & 7 days & $3.2 \mathrm{e}-2$ & $5.2 \mathrm{e}-2$ & $9.2 \mathrm{e}-2$ \\
\hline 0.9 & 30 days & $4.7 \mathrm{e}-2$ & $6.7 \mathrm{e}-2$ & $1.1 \mathrm{e}-1$ \\
\hline
\end{tabular}

Table 22. Fourplex; $\lambda=1 \mathrm{e}-5 /$ hour; $\delta=1000$ /hour

\begin{tabular}{|l|l|l|l|l|}
\hline $\begin{array}{l}\text { Diag } \\
\text { Level }\end{array}$ & $\begin{array}{l}\text { Regular } \\
\text { Maint } \\
\text { Period }\end{array}$ & $\begin{array}{l}\text { System } \\
\text { replaced } \\
\text { every } \\
1 \text { year }\end{array}$ & $\begin{array}{l}\text { System } \\
\text { replaced } \\
\text { every } \\
2 \text { years }\end{array}$ & $\begin{array}{l}\text { System } \\
\text { replaced } \\
\text { every } \\
5 \text { years }\end{array}$ \\
\hline 0.999 & 1 day & $4.1 e-4$ & $7.3 e-4$ & $1.3 e-3$ \\
\hline 0.999 & 7 days & $4.1 e-4$ & $7.4 e-4$ & $1.3 e-3$ \\
\hline 0.999 & 30 days & $5.7 e-4$ & $8.9 e-4$ & $1.5 e-3$ \\
\hline & & & & \\
\hline 0.99 & 1 day & $\mathbf{4 . 0 e - 3}$ & $\mathbf{7 . 3 e - 3}$ & $1.3 \mathrm{e}-2$ \\
\hline 0.99 & 7 days & $\mathbf{4 . 0 e - 3}$ & $\mathbf{7 . 3 e - 3}$ & $1.3 \mathrm{e}-2$ \\
\hline 0.99 & 30 days & $\mathbf{4 . 1 e - 3}$ & $\mathbf{7 . 3 e - 3}$ & $1.4 \mathrm{e}-2$ \\
\hline & & & & \\
\hline 0.9 & 1 day & $3.9 \mathrm{e}-2$ & $7.0 \mathrm{e}-2$ & $1.2 \mathrm{e}-1$ \\
\hline 0.9 & 7 days & $3.9 \mathrm{e}-2$ & $7.0 \mathrm{e}-2$ & $1.2 \mathrm{e}-1$ \\
\hline 0.9 & 30 days & $3.9 \mathrm{e}-2$ & $6.8 \mathrm{e}-2$ & $1.3 \mathrm{e}-1$ \\
\hline
\end{tabular}

Table 23. Fourplex; $\lambda=1 \mathrm{e}-5 /$ hour $; \delta=10000 /$ hour

\begin{tabular}{|l|l|l|l|l|}
\hline $\begin{array}{l}\text { Diag } \\
\text { Level }\end{array}$ & $\begin{array}{l}\text { Regular } \\
\text { Maint } \\
\text { Period }\end{array}$ & $\begin{array}{l}\text { System } \\
\text { replaced } \\
\text { every } \\
1 \text { year }\end{array}$ & $\begin{array}{l}\text { System } \\
\text { replaced } \\
\text { every } \\
2 \text { years }\end{array}$ & $\begin{array}{l}\text { System } \\
\text { replaced } \\
\text { every } \\
5 \text { years }\end{array}$ \\
\hline 0.999 & 1 day & $4.1 e-4$ & $7.3 e-4$ & $1.3 e-3$ \\
\hline 0.999 & 7 days & $4.1 e-4$ & $7.4 e-4$ & $1.4 e-3$ \\
\hline 0.999 & 30 days & $5.7 e-4$ & $8.9 e-4$ & $1.5 e-3$ \\
\hline & & & & \\
\hline 0.99 & 1 day & $\mathbf{4 . 0 e - 3}$ & $7.3 \mathrm{e}-3$ & $1.3 \mathrm{e}-2$ \\
\hline 0.99 & 7 days & $\mathbf{4 . 0 e - 3}$ & $7.3 \mathrm{e}-3$ & $1.3 \mathrm{e}-2$ \\
\hline 0.99 & 30 days & $\mathbf{4 . 1 e - 3}$ & $7.3 \mathrm{e}-3$ & $1.4 \mathrm{e}-2$ \\
\hline & & & & \\
\hline 0.9 & 1 day & $3.9 \mathrm{e}-2$ & $7.0 \mathrm{e}-2$ & $1.2 \mathrm{e}-1$ \\
\hline 0.9 & 7 days & $3.9 \mathrm{e}-2$ & $7.0 \mathrm{e}-2$ & $1.2 \mathrm{e}-1$ \\
\hline 0.9 & 30 days & $3.9 \mathrm{e}-2$ & $6.8 \mathrm{e}-2$ & $1.3 \mathrm{e}-1$ \\
\hline
\end{tabular}


Table 24. Fiveplex; $\lambda=1 \mathrm{e}-5 /$ hour

\begin{tabular}{|l|l|l|l|l|}
\hline $\begin{array}{l}\text { Diag } \\
\text { Level }\end{array}$ & $\begin{array}{l}\text { Regular } \\
\text { Maint } \\
\text { Period }\end{array}$ & $\begin{array}{l}\text { System } \\
\text { replaced } \\
\text { every } \\
1 \text { year }\end{array}$ & $\begin{array}{l}\text { System } \\
\text { replaced } \\
\text { every } \\
2 \text { years }\end{array}$ & $\begin{array}{l}\text { System } \\
\text { replaced } \\
\text { every } \\
5 \text { years }\end{array}$ \\
\hline 0.999 & 1 day & $8.3 e-7$ & $1.2 e-6$ & $2.6 e-6$ \\
\hline 0.999 & 7 days & $2.6 e-5$ & $2.8 e-5$ & $3.3 e-5$ \\
\hline 0.999 & 30 days & $4.4 e-4$ & $4.5 e-4$ & $4.8 e-4$ \\
\hline & & & & \\
\hline 0.99 & 1 day & $9.0 e-6$ & $2.6 e-5$ & $1.0 e-4$ \\
\hline 0.99 & 7 days & $4.8 e-5$ & $8.0 e-5$ & $1.9 e-4$ \\
\hline 0.99 & 30 days & $5.1 e-4$ & $5.9 e-4$ & $8.7 e-4$ \\
\hline & & & & \\
\hline 0.9 & 1 day & $\mathbf{6 . 0 e}-4$ & $\mathbf{2 . 0 e - 3}$ & $\mathbf{8 . 8 e - 3}$ \\
\hline 0.9 & 7 days & $\mathbf{7 . 6 e - 4}$ & $\mathbf{2 . 3 e - 3}$ & $\mathbf{9 . 4 e - 3}$ \\
\hline 0.9 & 30 days & $\mathbf{1 . 6 e - 3}$ & $\mathbf{3 . 5 e - 3}$ & $1.2 \mathrm{e}-002$ \\
\hline
\end{tabular}

\section{Results for Preventive Maintenance}

An overall result is that there is very little gain when the component failure rate is $1 \mathrm{e}-4$. Only for the fiveplex is there a gain, and this gain is small. The diagnostic level can drop to $99 \%$, but daily regular-maintenance is required, and the system must be replaced every year or every two years.

For the threeplex under daily regularmaintenance, the diagnostic level can drop to $99 \%$, and the system can be replaced every one, two, or five years. For the threeplex under weekly regularmaintenance, the diagnostic level can drop to $99 \%$, and the system can be replaced every one or two years.

For a given diagnostic level, a double-dual does not perform as well as a threeplex, but it may be easier to obtain a high diagnostic level with a double-dual.

For both fourplexes, the diagnostic level can drop to $99 \%$ and regular-maintenance can be reduced to monthly if the system is replaced within two years. An anomaly is that under daily regularmaintenance, it is sufficient to replace the threeplex but not the fourplexes within five years.

For the fiveplex under daily or weekly maintenance, the diagnostic level can drop to $90 \%$ if the system is replaced within five years. For the fiveplex under monthly maintenance, the diagnostic level can drop to $90 \%$ if the system is replaced within two years.

If a high diagnostic level is difficult to achieve or establish, then the fiveplex with high quality components and preventive maintenance is the system of choice.

\section{Summary}

Markov models were used to determine the component, system, and maintenance requirements needed to meet the reliability goal of a system operating continuously over a ten year period. The models were flexible enough to examine the effects of all these factors.

In general, high reliability for a long period requires a combination of quality components, redundancy, good diagnostics, and frequent maintenance. Since a high diagnostic level is one of the more difficult goals to achieve, this study recommends high quality components and a sufficient amount of redundancy.

This paper is an application of standard material [1,2]. The major difference is that the usual study of reliability only includes the period between maintenance checks $[3,4]$, not the accumulation of faults over a long operating period.

\section{References}

[1] William Feller, "An Introduction to Probability Theory and It's Applications", Volume I, Wiley, New York, 1968.

[2] M. Hirsch and S. Smale, "Differential Equations, Dynamical Systems, and Linear Algebra", Academic Press, New York, 1974

[3] C. Walter, "Evaluation and design of an ultrareliable distributed architecture for fault tolerance," IEEE Transactions on Reliability, Volume 39, Issue 4 (1990), pp. 492-499.

[4] C. Stroud, "Reliability of majority voting based VLSI fault-tolerant circuits," IEEE Transaction on Very Large Scale Integration, Volume 2, Issue 4, (1994), pp. 516-521. 